\title{
Conservation news
}

\section{What's in a name? Wildlife traders evade authorities using code words}

Where rare species are concerned, including those with restricted range, their use for traditional medicine can have disastrous impacts on local populations already under pressure (UN Office on Drugs and Crime, 2016, http://www. unodc.org/documents/data-and-analysis/wildlife/World_ Wildlife_Crime_Report_2016_final.pdf). Difficulty in monitoring such illegal activity has been illustrated by enforcement raids across India since June 2017 (National Geographic, 7 July 2017, https://news.nationalgeographic. com/2017/o7/wildlife-watch-india-monitor-lizard-poachingplant-root-hatha-jodi/), with authorities seizing supposedly rare Himalayan plant roots referred to as hatha jodi.

Hatha jodi (Plate 1) is purported to have magical powers to ward off bad luck and change lives, bringing wealth, power and contentment. These qualities make it an attractive purchase on Hindu tantric stores and websites. However, laboratory examinations in India and the UK in May 2017 have confirmed that hatha jodi is actually the dried hemipenes of Indian monitor lizards (Bengal monitor Varanus bengalensis and yellow monitor Varanus flavescens). The penalty for killing these species or dealing in their body parts is equivalent to doing so with a tiger in India (Wildlife Protection Act 1972 of India) and internationally (CITES Appendices, 2017).

This raises the question of whether customers and traders really believe they are dealing with plant roots. Is this, rather, a cover to disguise trade in protected lizards through the deliberate use of a code word? The latter would seem likely, as we documented hundreds of such advertisements carried by online retailers during a search made over a 4 week period in June 2017. The retailers included Amazon, eBay and Alibaba, which presumably did not realise they

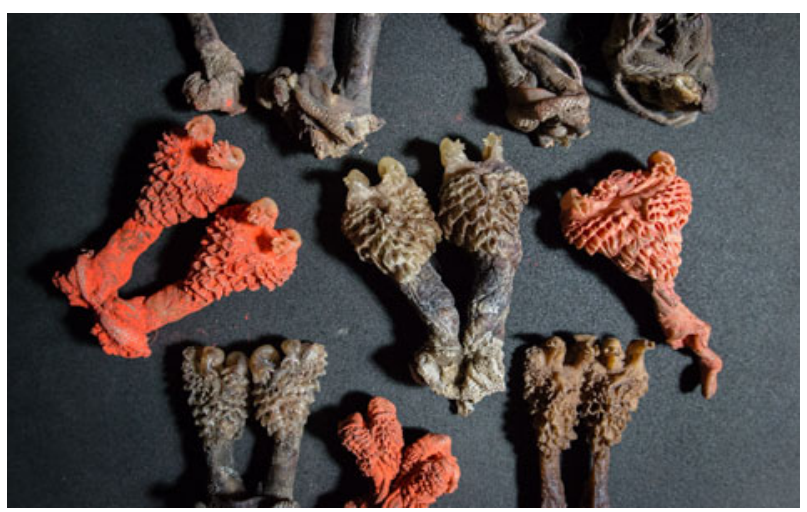

Plate 1 Monitor lizard (Varanus spp.) genitalia, sold as Hatha Jodi, a Himalayan plant root, by major online retailers. Image (c) Neil D’Cruze. were involved in illegal sales, at prices of up to USD 250 apiece, of a species protected across Asia, Europe and North America.

Perhaps exaggerated respect given to spiritual myths thickened the smoke screen by trading unscrupulously on the religious connotations of hatha jodi (Frontiers in Ecology and the Environment, 2015, 13, 325). Either way, when it comes to illegal trade, the Shakespearian question 'What's in a name?' reveals more loopholes than a knitted scarf. We believe that, for effective enforcement of wildlife trade laws, in addition to a standardized naming policy based on up-to-date taxonomic classification (Conservation Letters, 2016, 9, 313), creation of a readily accessible list of colloquial names used as codes to sell globally protected species is essential.

NeIL D'Cruze* Bhagat Singh, Aniruddha MookerJee and DAVID W. MACDONALD Wildlife Conservation Research Unit, The Recanati-Kaplan Centre, Department of Zoology, University of Oxford, Oxford, UK.

E-mail neil.dcruze@zoo.ox.ac.uk

Katie Hunter, Charlotte A. Brassey, Jennifer Rowntree, SteVEn Megson, DaVID MEGSON and Graeme Fox School of Science and Environment, Manchester Metropolitan University, Manchester, UK

JOSE LOUIES Wildlife Trust of India, Noida, India

Ratnakaran SHANTA SHarath Wildlife Crime Control Bureau, New Delhi, India

${ }^{*}$ Also at World Animal Protection, London, UK

\section{Rediscovery of the chinchilla in Bolivia}

On 19 April 2017, during a routine inspection in the Laguna Colorada region of the National Reserve of Andean Fauna "Eduardo Avaroa" (the specific locality is not be identified for security reasons), ED, alerted by animal calls, discovered a burrow under a large boulder. With local help he excavated the burrow and found four short-tailed chinchillas Chinchilla chinchilla of different ages and sexes; two additional individuals were discovered inside the den the next day. All individuals were returned to their burrow 3 days later after measurements and photographs had been taken.

This chinchilla is one of two species native to the Andes. The last verified report of the presence of the short-tailed chinchilla in Bolivia dates from 1939 (S. Anderson, 1997, Mammals of Bolivia, Bulletin of the American Museum of Natural History, 231, 1-652). For this reason, it was thought to be the first Bolivian mammal to have gone extinct in the 
wild, but it was later recategorized as Critically Endangered (T. Tarifa, 2009, Chinchilla chinchilla, In Libro rojo de la fauna silvestre de vertebrados de Bolivia, pp. 457-459, Ministerio de Medio Ambiente y Agua, La Paz, Bolivia) based on undocumented reports by residents of peasant communities in the southern department of Potosí. Fieldwork across the highlands of Bolivia failed, however, to verify the occurrence of the species.

Overexploitation of wild chinchilla populations for their valuable pelts in the 19th and early 2oth century is thought to have been the main cause of the decline of this species across its former range. The species is categorized as Endangered on the IUCN Red List. Historically broadly distributed, chinchillas inhabited the coast and the Andes of central Peru to the south through the high Andean regions of central-west Bolivia, northern Chile, and north-west Argentina. It was recently rediscovered in northern Chile (P. Valladares et al., 2014. Animal Biodiversity and Conservation, 37, 89-93). Although the chinchilla was previously considered extinct in Peru, there is potentially an extant population in the remote central highlands (A. Spotorno \& J. Patton, 2015, Superfamily Chinchilloidea Bennet, 1833. In Mammals of South America, Volume 2 Rodents, eds J.L. Patton et al., pp. 762-783, The University of Chicago Press, USA).

The National Reserve of Andean Fauna "Eduardo Avaroa" is a flagship conservation unit of the Bolivian National Park system, covering the dry Puna region of southern Bolivia. The fauna of the Reserve is characterized by species adapted to the extreme conditions of the region, including the Endangered Andean mountain cat Leopardus jacobita and Vulnerable Andean Flamingo Phoenicoparrus andinus. These species and habitats are under increasing threats from tourism and climate change.

The current management plan of the Reserve does not include provisions to protect the newly found population of chinchillas and there is an urgent need to include stakeholders and policy makers in development of a long-term plan for the protection of this unique fauna, of which chinchillas are a major component. Initial contacts towards this goal are ongoing.

Eliseo Delgado Servicio Nacional de Areas Protegidas Reserva Nacional de Fauna Andina "Eduardo Avaroa", Uyuni, Potosí, Bolivia

Luis FeRNANDo PACHECo Universidad Mayor de San Andrés Instituto de Ecología, La Paz, Bolivia

Jorge Salazar-Bravo Department of Biological Sciences, Texas Tech University, Lubbock, Texas, USA. E-mail j.salazar-bravo@ttu.edu

OMar Rocha Centro de Estudios en Biología Teórica y Aplicada-Direccion Ejecutiva, La Paz, Bolivia

\section{Coal mining threatens the Vulnerable aquatic warbler Acrocephalus paludicola}

The aquatic warbler Acrocephalus paludicola, categorized as Vulnerable on the IUCN Red List, is a species particularly affected by hydrological changes, including to wetland habitats. The global population of this species decreased by $>90 \%$ in the 20 th century, and there are currently only $10,200-13,800$ singing males, breeding in an area of $1,000 \mathrm{~km}^{2}$ (BirdLife International, 2008, International Species Action Plan for the Aquatic Warbler Acrocephalus paludicola. Updated version, 2010). A new threat to the aquatic warbler has now arisen: potential coal mining within a few kilometres of Bubnów Marsh in Polesie National Park, Poland.

Bubnów Marsh, close to the Polish-Ukrainian-Belarus border, is one of the largest calcareous fen mires in Europe. It is a significant wetland area that survived drainage during the communist era. This marsh is protected by the Ramsar Convention on Wetlands, is an Important Bird and Biodiversity Area, a Cross-border Biosphere Reserve (Polesie Zachodnie) and a Natura 2000 area. In 2014389 singing males of the aquatic warbler were found in the marsh (G. Grzywaczewski, 2015, Annales UMCS section EE, $33,1-12$ ), representing $3-4 \%$ of the global population.

The Chief Geologist in Poland has approved a concession for a company that is planning construction of coal mine near Bubnów Marsh. In May 2017, during proceedings of the scientific council of Polesie National Park, a representative of the company that carried out the exploratory drilling presented the prospects for future coal mining in the vicinity of the marsh. The company plans to mine coal for $\mathrm{c}$. 10 years (Wspólnota Łęczyńska, 4 October 2016, http://24wspolnota. $\mathrm{pl} /+$ wlj8n). Local councils and government representatives are involved in lobbying in favour of the construction of the new mine (authors, pers. obs.).

An alternative source of income in this area could be ecotourism. Polesie National Park was visited by c. 44,00o tourists in 2016 (Tourist Register of Polesie National Park, unpubl. data), and Urszulin Commune, which includes the Park, receives grants from the European Union budget for the promotion and development of tourist infrastructure. Coal mining will have a negative impact on this valuable wetland ecosystem, potentially resulting in the loss of habitats and rare species, including the aquatic warbler. Mining could also result in the reduction of tourism and a loss of income that would help improve the development of tourism and recreation.

Grzegorz GRZYWACZEWSKI Department of Zoology, Animal Ecology and Wildlife Management, University of Life Sciences in Lublin, Lublin, Poland.

E-mail grzegorz.grzywaczewski@up.lublin.pl

IGNACY KITOWSKI The State School of Higher Education in Chetm, Chetm, Poland 